This is the accepted version of: 'Groundwater Regulation in India: Applicability of Public Trust Doctrine and Right to Participation in Decision Making to achieve Right to Water.' In: Rehman, Javaid and Shahid, Ayesha, (eds.), Islamic Law and its Implementation in Asia and the Middle East. Leiden: Brill, pp. 327-349. (The Asian Yearbook of Human Rights and Humanitarian Law; Vol. 2). Published version available from:

https://brill.com/abstract/book/edcoll/9789004346888/B9789004346888 012.xml

Accepted version downloaded from SOAS Research Online: https://eprints.soas.ac.uk/26433/

\title{
Groundwater Regulation in India: Applicability of Public Trust Doctrine and Right to Participation in Decision Making to achieve Right to Water
}

\author{
Gayathri D Naik*
}

\begin{abstract}
:
Groundwater is the key source for irrigation, industrial and domestic uses in India. It is extensively relied upon in different parts of the country without taking into consideration, hydrological nature and availability of water resources resulting in depletion of groundwater at an alarming rate. Existing legal framework along with several other factors add up to this situation. Groundwater- landownership nexus proves to be the hurdle in effective groundwater regulation and management. Present laws only focus on regulation of use and do not provide for conservation of groundwater. These laws do not change the ownership status. In the light of increasing demand for water for drinking and agricultural purposes, and need for realization of human right to water, there is urgent need to delink groundwater landownership nexus by applying public trust doctrine to groundwater like surface water. Supreme Court of India has already declared rivers and lakes in the country to be held by the state as public trustee but the same has not been applied to groundwater resources. This paper focuses on the applicability of public trust doctrine to groundwater resources in India to ensure its effective conservation. There have been several instances around the world where public trust doctrine has been applied by the courts for groundwater conservation. The principle developed from Roman law has been applied in several jurisdictions for natural resources management. This paper analyses how this principle can be applied in Indian situation for groundwater conservation. For successful application of these reforms, public participation in decision making is inevitable. The affected/ to be affected sections of the society should be included especially in environmental issues. The paper also focuses on the need for public participation in groundwater related issues in India. Though both these elements have been incorporated by the central government in the
\end{abstract}

\footnotetext{
*Research Scholar at School of Law, SOAS, University of London. She is presently the Commonwealth Scholar for $\mathrm{PhD}$ in Law from India (2017). She holds BAL.LLB(MG University, Kerala) MPA(IGNOU,New Delhi) LLM in International Legal Studies(South Asian University, New Delhi).
} 
This is the accepted version of: 'Groundwater Regulation in India: Applicability of Public Trust Doctrine and Right to Participation in Decision Making to achieve Right to Water.' In: Rehman, Javaid and Shahid, Ayesha, (eds.), Islamic Law and its Implementation in Asia and the Middle East. Leiden: Brill, pp. 327-349. (The Asian Yearbook of Human Rights and Humanitarian Law; Vol. 2). Published version available from: https://brill.com/abstract/book/edcoll/9789004346888/B9789004346888 012.xml Accepted version downloaded from SOAS Research Online: https://eprints.soas.ac.uk/26433/

recently introduced bills, these reforms remain still a distant dream in case of groundwater reforms in India due to landownership-groundwater nexus.

Key words: Groundwater regulation, India, Public Trust Doctrine, Public Participation in Decision Making

\section{Introduction}

Groundwater is the main source of water for drinking and agricultural purposes in the South Asian region. South Asia, especially India constitutes the largest exploiter of groundwater in the world. Initiation of green revolution and subsequent introduction of hybrid variety seeds and water rich crops, power subsidies for irrigation added complexity to the situation. Right to water has been recognized as a human right and fundamental right by various judicial forums across the region. However, there is no clear pronouncement as to whether the fundamental right to water also includes in its ambit groundwater.

International law on groundwater is still in nascent stage. The only legal instrument is the 2008 ILC Draft on Trans-boundary aquifers. Groundwater regulation in South Asia still follows Common law principle of groundwater being considered as a 'chattel' attached to land, although there has been an attempt to change the legislation by introducing the principle of public trust and common heritage of mankind to regulate this resource.

In the light of increased water scarcity and the rising concerns of degradation and pollution of water resources, this article analyses the applicability of public trust doctrine and the right to 
This is the accepted version of: 'Groundwater Regulation in India: Applicability of Public Trust Doctrine and Right to Participation in Decision Making to achieve Right to Water.' In: Rehman, Javaid and Shahid, Ayesha, (eds.), Islamic Law and its Implementation in Asia and the Middle East. Leiden: Brill, pp. 327-349. (The Asian Yearbook of Human Rights and Humanitarian Law; Vol. 2). Published version available from: https://brill.com/abstract/book/edcoll/9789004346888/B9789004346888 012.xml Accepted version downloaded from SOAS Research Online: https://eprints.soas.ac.uk/26433/ participation in decision making in groundwater regulation in India. Public trust doctrine has been successfully applied in natural resources management in several countries. In several instances, this has been applied in protecting water resources and especially groundwater resources. The article looks into the development of public trust doctrine and its applicability in protecting groundwater resources in the first section. The application of the doctrine in India is also discussed and special focus is given to groundwater resources protection and public trust doctrine. The second section focuses on the right to participation in decision making and its application in groundwater resources protection in India. This section also examines international and regional conventions especially Aarhus Convention to address the issue of public participation in decision making in environmental issues and how these can be applied in India to ensure groundwater protection.

\section{Public Trust Doctrine}

Public trust doctrine has its origin in Roman law in the Declaration of Justinian that:

By the law of nature these things are common to all mankind-the air, running water, the sea, and consequently the shores of the sea. No one, therefore, is forbidden to approach the seashore, provided that he respects habitations, monuments, and buildings, which are not, like the sea, subject only to the law of nations. . . All rivers and ports are public; hence the right of fishing in a port, or in rivers, is common to all men. . . The public use of the seashore, too, is part of the law of nations, as is that of the sea itself. ${ }^{1}$

1 J. Tuholske, 'Trusting the Public Trust: Application of the Public Trust Doctrine to Groundwater Resources' (2008) 9 Vermont Journal of Environmental Law 189, at 219. 
This is the accepted version of: 'Groundwater Regulation in India: Applicability of Public Trust Doctrine and Right to Participation in Decision Making to achieve Right to Water.' In: Rehman, Javaid and Shahid, Ayesha, (eds.), Islamic Law and its Implementation in Asia and the Middle East. Leiden: Brill, pp. 327-349. (The Asian Yearbook of Human Rights and Humanitarian Law; Vol. 2). Published version available from: https://brill.com/abstract/book/edcoll/9789004346888/B9789004346888 012.xml Accepted version downloaded from SOAS Research Online: https://eprints.soas.ac.uk/26433/ The Justinian principle has influenced the development of public trust doctrine all over the world. ${ }^{2}$ Under English Law, the ownership of the tidal lands vested in the King who held them in trust for the public. ${ }^{3}$ The inability to alienate public land held in trust however was not applicable to Parliament which enjoyed the authority to enlarge or dismiss any right through Statutes for the legitimate purposes. ${ }^{4}$ The English principle reformed the Roman Community ownership by delimitating public and private ownership of rights where the Sovereign could alienate only Jus privatum and not Jus publicum. ${ }^{5}$ The American model of Public Trust was influenced by both Roman and English principles ${ }^{6}$ but authority over the beds of navigable waters were passed to the States with title being neither absolute or nor inalienable. ${ }^{7}$

The doctrine has originally been associated with the public ownership of the beds beneath navigable waters and protection of navigation, commerce and fishing activities in such waters. ${ }^{8}$

2 R. Ausness, 'Water Rights, the Public Trust Doctrine, and the Protection of In stream Uses' (1986) University of Illinois Law Review 407,409.

3 D. Takacs, 'The Public Trust Doctrine, Environmental Human Rights, and the Future of Private Property' (2008)16 New York University Environmental Law Journal $711<$ http://www.ielrc.org/content/a0804.pdf $>$. See also Ausness (n 2) 408.

4 J.L. Sax, 'The Public Trust Doctrine in Natural Resource Law: Effective Judicial Intervention (1970) 68 Michigan Law Review 471, 476.

5 D.S. Fitzgerald, 'Extending Public Trust Duties to Vermont's Agencies: A Logical Interpretation of the Common Law Public Trust Doctrine' (1995) 19 Vermont Law Review 509, 511.

$6 \quad \operatorname{Sax}(\mathrm{n} 4) 476$.

$7 \quad$ Ibid. 519.

8 J.F. Smith, 'The Public Trust Doctrine and National Audubon Society v. Superior Court: A Hard Case makes bad Law or the consistent evolution of California Water Rights' (1984) 6 Glendale Law Review 201, 202. See also J. Stevens, 'The Public Trust Doctrine: A Sovereign's Ancient Prerogative Becomes the People's Environmental Right' (1980) 14 U C Davis Law Review 195, 195-196. Shively v. Bowl by 152 U.S. 1 (1894); Illinois Cent. R.R v. Illinois 146 U.S. 387 (1892); Martin v. Waddell 41 U.S. 367 (1842). 
This is the accepted version of: 'Groundwater Regulation in India: Applicability of Public Trust Doctrine and Right to Participation in Decision Making to achieve Right to Water.' In: Rehman, Javaid and Shahid, Ayesha, (eds.), Islamic Law and its Implementation in Asia and the Middle East. Leiden: Brill, pp. 327-349. (The Asian Yearbook of Human Rights and Humanitarian Law; Vol. 2). Published version available from: https://brill.com/abstract/book/edcoll/9789004346888/B9789004346888 012.xml Accepted version downloaded from SOAS Research Online: https://eprints.soas.ac.uk/26433/ Thus it mainly ensured public right to access and use the shoreline, the right to use the water by imposing a limitation on the state's ability to alienate under water lands. ${ }^{9}$ The American courts have extensively ruled that the doctrine extends beyond the traditional triad-commerce, navigation and fishing. ${ }^{10}$ Prior to this judicial expansion, the move to expand was initiated by Joseph Sax in 1970 in his seminal article ${ }^{11}$ portraying the doctrine as the 'effective tool of general application for citizens to develop a comprehensive legal approach to resource management problems.' ${ }^{12}$ He points out that for the tool to be effective, it must satisfy three criteria:

- Should contain some concept of legal right in the general public;

- It must be enforceable against the government

- It must be capable of an interpretation consistent with contemporary concerns for environmental quality. ${ }^{13}$

Joseph Sax is of the view that the doctrine imposes three types of restriction on the authority of government to convey the trust property.

9 P.E. Salkin, 'The Use of the Public Trust Doctrine as a Management Tool over Public and Private Lands.' (1994) 4 Albany Law Journal of Science \& Technology 1, 2.

10 E. Swenson, 'Public Trust Doctrine and Groundwater Rights' (1998) 53 University of Miami Law Review 363, 364; Ausness (n 2) 408; E Casey, 'Water law-public trust doctrine' (1984) 24 Natural Resources Journal 809, 815. The doctrine has been extended for the protection of public interests in areas like swimming, bathing, boating, aesthetics, wildlife etc. National Audubon Society v Superior Court of Alpine City (Mono Lake) 658 P.2d 702,712 (Cal.1983).

$11 \quad \operatorname{Sax}(n$ 4) 471.

$12 \quad$ Ibid. 474.

13 Ibid. 
This is the accepted version of: 'Groundwater Regulation in India: Applicability of Public Trust Doctrine and Right to Participation in Decision Making to achieve Right to Water.' In: Rehman, Javaid and Shahid, Ayesha, (eds.), Islamic Law and its Implementation in Asia and the Middle East. Leiden: Brill, pp. 327-349. (The Asian Yearbook of Human Rights and Humanitarian Law; Vol. 2). Published version available from: https://brill.com/abstract/book/edcoll/9789004346888/B9789004346888 012.xml Accepted version downloaded from SOAS Research Online: https://eprints.soas.ac.uk/26433/

- The trust property should not only be used for a public purpose but also be held available for use by the general public.

- The property may not be sold.

- It should be maintained for particular types of uses. ${ }^{14}$

The first American case to consider the doctrine was Carson v Blazer. ${ }^{15}$ In this case the Court expanded the English doctrine which applied only to tidal waters to non-tidal waters. ${ }^{16}$ The Supreme Court decision in Illinios Central Railroad Co. $v$ Illinios,${ }^{17}$ considered as the 'vanguard or lodestar' of public trust cases points out the judicial approach towards the doctrine. ${ }^{18}$ In this case, the Supreme Court held that '[T]he abdication of the general control of the State over lands under the navigable waters of an entire harbor or bay, or a sea or lake... is not consistent with the exercise of that trust which requires the government of the State to preserve such waters for the use of the public'. ${ }^{19}$ The two main tenets of the doctrine

$14 \quad$ Ibid. 477.

15 The Pennsylvania Supreme Court in Carson v Blazer, (1810) 2 Binn 475, expanded the doctrine to non-tidal waters through a Comparison with England. The court pointed that restricting the doctrine to tidal waters in England would be reasonable in England where there is no river so important to navigation, which does not have a flow of tide. The same would not be applicable to America where there are many navigable rivers, most of them being non-tidal.

16 D. Spiegel, 'Can the public trust doctrine save western Groundwater?' (2011) 18 New York University Environmental Law Journal 412, 425.

17146 U.S 387(1892). The question that arose in the case was whether the title granted by the Legislature to Illinois Central rail road in 1869 with respect to Chicago water front property was absolute or was subject to public trust? The legislature revoked the title in 1873 but the railroad refused to relinquish the same. Hence the suit arose on which the United States Supreme Court held that since the state holds the land beneath the harbor as a trustee, it is capable to revoke the grant at any time. See also Fitzgerald (n 5) 514.

18 Spiegel (n 16) 425.

19 Ausness (n 2) 407, at 412. 
This is the accepted version of: 'Groundwater Regulation in India: Applicability of Public Trust Doctrine and Right to Participation in Decision Making to achieve Right to Water.' In: Rehman, Javaid and Shahid, Ayesha, (eds.), Islamic Law and its Implementation in Asia and the Middle East. Leiden: Brill, pp. 327-349. (The Asian Yearbook of Human Rights and Humanitarian Law; Vol. 2). Published version available from: https://brill.com/abstract/book/edcoll/9789004346888/B9789004346888 012.xml

Accepted version downloaded from SOAS Research Online: https://eprints.soas.ac.uk/26433/

were underlined. Firstly, the traditional version limiting the doctrine to tidal waters was rejected by expanding the applicability to include navigable freshwater bodies like lakes, streams etc. Secondly, the ability of the state to convey trust property to private use was limited by public trust in common resources which requires the state should ensure that the private use should benefit the public interest in navigation, swimming etc. ${ }^{20}$

The Californian High Court in its seminal judgment in National Audubon Society v Superior Court of Alpine City (Mono Lake) ${ }^{21}$ expanded the scope of the doctrine and highlighted that though it was initially limited to navigation, fishing and commerce, now it has to be expanded to include protection of environmental and recreational values. ${ }^{22}$ The Wisconsin Supreme Court has observed that 'the active public trust duty ....requires the State not only to promote and preserve those waters for fishing, recreation and scenic beauty.' ${ }^{23}$

The doctrine does not prevent the state from conveying some portions of the trust property to private entities though it acts as a prohibition on the state's ability to completely surrender the control of public trust property. ${ }^{24}$ It was accepted since long that: $[\mathrm{t}]$ he state as trustee for the public cannot by acquiescence abandon the trust property or enable a diversion of it to private

20 Tuholske (n 1); See also Fitzgerald (n 5) 514.

21658 P.2d 709 (Cal. 1983), cert. denied, 464 U.S. 977 (1983).

$22 \quad$ Ibid. 217-218.

23 Just v Marinette County 56 Wis.2d 7,18,201 N.W.2d 761,768(1972) in V.P. Nanda \& W.K. Ris, Jr., 'The Public Trust Doctrine: A Viable Approach to International Environmental Protection' (1976) 5 Ecology Law Quarterly 291,302.

24 Illinios Central Rail Road v Illinios 146 U.S 387, 452(1892) in Ausness (n 2) 412. 
This is the accepted version of: 'Groundwater Regulation in India: Applicability of Public Trust Doctrine and Right to Participation in Decision Making to achieve Right to Water.' In: Rehman, Javaid and Shahid, Ayesha, (eds.), Islamic Law and its Implementation in Asia and the Middle East. Leiden: Brill, pp. 327-349. (The Asian Yearbook of Human Rights and Humanitarian Law; Vol. 2). Published version available from: https://brill.com/abstract/book/edcoll/9789004346888/B9789004346888 012.xml Accepted version downloaded from SOAS Research Online: https://eprints.soas.ac.uk/26433/ ends different from the object for which the trust was created. ${ }^{25}$ Prof. Sax notes that at present there is 'no general prohibition against the disposition of the trust properties, even at a large scale.' ${ }^{26}$ The state can alienate the property to private ownership to promote navigation purposes or other trust purposes. ${ }^{27}$ The duty bestowed upon the state under this doctrine is that of trustee which has 'high fiduciary duty of care and responsibility to the general public'. ${ }^{28}$ The duty not only includes obligation to preserve the trust property but also to seek injunction against and compensation for its diminution. ${ }^{29}$ The state cannot abandon its obligation to protect its trust property which implies that if the property is alienated by the trustee the trust remains attached and enforceable. ${ }^{30}$ The state is under an obligation to prove that such transfer was necessary for the promotion and benefit of the interests of the trust beneficiaries (public in general). ${ }^{31}$ It should strike a balance to ensure that the public use is consistent with development and industrialization. ${ }^{32}$

25 The Ohio Supreme Court noted in State v. Cleveland \& Pittsburgh R.R., 94 Ohio St. 61, 80, 113 N.E. 677, 682 (1916) in Sax (n 4) 471 at 486.

26 Ibid.

27 Ausness (n 2) 412.

28 B.S. Cohen, 'The Constitution, The Public Trust Doctrine, and the Environment' (1970) Utah Law Review 388. The author quotes 'The state as trustee for the public cannot, by acquiescence, abandon the trust property or enable a diversion of it to private ends different from the object for which the trust was created' from State $v$. Cleveland \& P.R.R. 94 Ohio St. 61, 80, 113 N.E. 677, 682 (1916). See also Sax (n 4) 485.

$29 \quad$ Nanda \& Ris. Jr.(n 23) 291, at 303.

30 Sax (n 4) 471, at 487.

31 Cohen (n 28) 391.

32 Nanda \& Ris. Jr., (n 23) 291, at 303. 
This is the accepted version of: 'Groundwater Regulation in India: Applicability of Public Trust Doctrine and Right to Participation in Decision Making to achieve Right to Water.' In: Rehman, Javaid and Shahid, Ayesha, (eds.), Islamic Law and its Implementation in Asia and the Middle East. Leiden: Brill, pp. 327-349. (The Asian Yearbook of Human Rights and Humanitarian Law; Vol. 2). Published version available from: https://brill.com/abstract/book/edcoll/9789004346888/B9789004346888 012.xml Accepted version downloaded from SOAS Research Online: https://eprints.soas.ac.uk/26433/ Public Trust and Water Resources Protection

The importance of protection of water resources under the Public trust was highlighted by Oregon Court of Appeals ruling in Morse v. Oregon Division of State Lands ${ }^{33}$ that:

[T] he severe restriction upon the power of the state as trustee to modify water resources is predicated not only upon the importance of the public use of such waters and lands, but upon the exhaustible and irreplaceable nature of the resources and its fundamental importance to our society and to our environment. These resources can after all be spent only once. Therefore, the law has historically and consistently recognized that rivers and estuaries once destroyed or diminished may never be restored to the public and, accordingly, has required the highest degree of protection from the public trustee. ${ }^{34}$

Later the Supreme Court of California observed in National Audubon Society v Superior Court of Alpine County (Mono Lake) ${ }^{35}$ that the doctrine imposes upon the state a duty of continuing supervision over the taking and using the appropriated water. ${ }^{36}$ The doctrine was extended by courts to all navigable lakes and streams including conducts affecting upstream

33581 P.2d 520 (Or. App. 1978)

34 Morse v. Oregon Division of State Lands 581 P.2d 520 (Or. App. 1978) See also H. Ingram and C.R. Oggins, 'The Public Trust Doctrine and Community Values in Water' (1992) 32 Natural Resources Journal 515, 521.

35658 P.2d 709 (Cal. 1983), cert. denied, 464 U.S. 977 (1983). Los Angeles withdrew water from Mono Lake, second largest lake in California under the permit granted by city water board which affected water quantity adversely. Sierra Club of San Francisco and the Washington-based National Audubon Society approached the Superior Court of Mono County for injunction which was later transferred to the Court in California. The plaintiff argued that water in the Mono Lake is public trust and State is duty bound to protect the trust property independent to its role of administrator of water appropriation.

36 Ausness (n 2) 423. 
This is the accepted version of: 'Groundwater Regulation in India: Applicability of Public Trust Doctrine and Right to Participation in Decision Making to achieve Right to Water.' In: Rehman, Javaid and Shahid, Ayesha, (eds.), Islamic Law and its Implementation in Asia and the Middle East. Leiden: Brill, pp. 327-349. (The Asian Yearbook of Human Rights and Humanitarian Law; Vol. 2). Published version available from: https://brill.com/abstract/book/edcoll/9789004346888/B9789004346888 012.xml

Accepted version downloaded from SOAS Research Online: https://eprints.soas.ac.uk/26433/

non- navigable water bodies which is likely to result in injuries to downstream navigable water bodies. ${ }^{37}$

It was observed that the state has an affirmative duty to consider the doctrine in planning and allocation of water resources and also to protect the public trust uses wherever feasible. It also held that appropriation of water without due consideration of public trust may cause unnecessary and unjustified harm. The Court also highlighted that even after the state approved appropriation of water, the public trust imposes a duty of continuing supervision over the same. ${ }^{38}$ The doctrine as applied in water context requires the state 'to balance economic needs against environmental values in granting water rights but at the same time the state should retain the control to determine whether this balance is consistent with modern public needs'. ${ }^{39}$ The Supreme Court of California elaborated four principles that define the doctrine as applied in water rights context:

- State being sovereign 'retains continuing supervisory control' over navigable waters and underlying beds.

- The legislature enjoys the right to grant usufructuary water rights even though such rights will 'not promote, and may unavoidably harm, the trust uses at the source stream';

- The state has the 'affirmative duty' to take the public trust into account in planning and allocating water resources; and

- The state has a 'duty of continuing supervision' over water rights even after such rights have been granted. ${ }^{40}$

37 J.F. Smith, 'The Public Trust Doctrine and National Audubon Society v. Superior Court: A Hard Case makes bad Law or the consistent evolution of California Water Rights' (1984) 6 Glendale Law Review 201, 214.

38 Ingram and Oggins (n 34) 525.

39 R E. Walston, 'The Public Trust Doctrine in the Water Rights Context' (1989) 29 Natural Resources Journal 585,588 .

40 Ibid. 
This is the accepted version of: 'Groundwater Regulation in India: Applicability of Public Trust Doctrine and Right to Participation in Decision Making to achieve Right to Water.' In: Rehman, Javaid and Shahid, Ayesha, (eds.), Islamic Law and its Implementation in Asia and the Middle East. Leiden: Brill, pp. 327-349. (The Asian Yearbook of Human Rights and Humanitarian Law; Vol. 2). Published version available from: https://brill.com/abstract/book/edcoll/9789004346888/B9789004346888 012.xml

Accepted version downloaded from SOAS Research Online: https://eprints.soas.ac.uk/26433/

Public trust doctrine when applied in the context of water provides the basis for considering water without the property perspective unlike the traditional principle followed in several countries where water rights being linked with the property rights. ${ }^{41}$ Under this doctrine, ' $[\mathrm{t}] \mathrm{he}$ State, which holds the natural waters as a trustee, is duty bound to distribute or utilize the waters in such a way that it does not violate the natural right to water of any individual or group and safeguards the interest of the public and of ecology (or nature) ${ }^{4}{ }^{42}$ Thus, public trust doctrine can be effectively used to conserve water resources. Can the doctrine be extended to regulation, conservation and development of groundwater resources?

\section{Groundwater Resources Protection and Public Trust Doctrine}

Danielle Spiegel points out that the applicability of the doctrine to groundwater would face three key obstacles: 'navigability, conservation being not in the list of protected list and third being uncertainty of the scope of retroactive powers of the doctrine.' ${ }^{43}$ However, since public trust doctrine is often linked with water and water being a common good, more significant than beds and banks of water bodies owned by the sovereign state, there is no reason to attach

41 P. Cullet, Water Law, Poverty and Development: Water Sector Reforms in India (1st edn, OUP 2009) 42.

42 C. Singh, Water Rights and principles of Water Resources management (N.M Tripathi 1991) 76.

43 Spiegel (n 16) 430. 
This is the accepted version of: 'Groundwater Regulation in India: Applicability of Public Trust Doctrine and Right to Participation in Decision Making to achieve Right to Water.' In: Rehman, Javaid and Shahid, Ayesha, (eds.), Islamic Law and its Implementation in Asia and the Middle East. Leiden: Brill, pp. 327-349. (The Asian Yearbook of Human Rights and Humanitarian Law; Vol. 2). Published version available from: https://brill.com/abstract/book/edcoll/9789004346888/B9789004346888 012.xml Accepted version downloaded from SOAS Research Online: https://eprints.soas.ac.uk/26433/ the applicability of doctrine to the criteria of land ownership and navigability. ${ }^{44}$ Realizing the surface water-groundwater hydrology ${ }^{45}$ and importance of groundwater, there are instances where the courts and statutes have applied the doctrine to groundwater. The decision of the Supreme Court of Hawaii in In re Water use Permit Applications (Wai'Hole Ditch) ${ }^{46}$ extends the public trust doctrine to groundwater resources too after relying on Common Law and the Hawaii Constitutional Amendments. ${ }^{47}$ In this case the Court focused on water itself citing that 'public trust doctrine applies to all waters without exception or distinction (including surface water and groundwater)' rather than the traditional notions of navigability. ${ }^{48}$ Pointing out that public trust by its very nature does not remain static every time but should conform to changing needs of the

44 Tuholske (n 1) 222-223.

45 According to Hawaii Supreme Court in In re Water use Permit Applications 9,P.3d 409 (Haw.2000) '[M]odern science and technology have discredited the surface-ground dichotomy' in J.T. Paul, 'The August, 2000 Hawaii Supreme Court Wai Hole Ditch Decision: Comments and Excerpts regarding Public Trust Doctrine' $5<$ http://www.hawaii.edu/ohelo/pleadings/WaiholeSummary.pdf>.

46 9,P.3d 409 (Haw.2000). In this case, Wai' Hole Ditch diverted water from windward sides Koolau mountain range on Oahu Island for use on Oahu plains resulting in dewatering of windward streams and substantial detriment of ecosystem and life of communities. While there was valid permit allotted by the water Commission for leeward users to extract water from the windward side, the Supreme Court of Hawaii in August 2000 set aside Commission's decision to grant permit to leeward side for agricultural uses by endorsing public trust doctrine.

47 Tuholske (n 1) 219. Art XI Section 1 of the Hawaii Constitution: '[F]or the benefit of present and future generations, the State and its political subdivisions shall conserve and protect Hawaii's natural beauty and all natural resources, including land, water, air, minerals and energy sources, and shall promote the development and utilization of these resources in a manner consistent with their conservation and in furtherance of the selfsufficiency of the State'. All public natural resources are held in trust by the State for the benefit of the people. Art XI Section 7 provides that: '[T]he State has an obligation to protect, control and regulate the use of Hawaii's water resources for the benefit of its people <http://www.lwvhawaii.com/govt/constitution/art11.htm\#07>.

$48 \quad$ Paul (n 45) 5. 
This is the accepted version of: 'Groundwater Regulation in India: Applicability of Public Trust Doctrine and Right to Participation in Decision Making to achieve Right to Water.' In: Rehman, Javaid and Shahid, Ayesha, (eds.), Islamic Law and its Implementation in Asia and the Middle East. Leiden: Brill, pp. 327-349. (The Asian Yearbook of Human Rights and Humanitarian Law; Vol. 2). Published version available from: https://brill.com/abstract/book/edcoll/9789004346888/B9789004346888 012.xml Accepted version downloaded from SOAS Research Online: https://eprints.soas.ac.uk/26433/ time. ${ }^{49}$ The doctrine being a dual concept of sovereign right and responsibility, ${ }^{50}$ bestows upon the state both the authority and duty to preserve the rights of present and future generations in the waters of the state. ${ }^{51}$ This authority not only prevents the state from granting or assertion of any vested rights to use water in detrimental to the purposes of public trust but casts an affirmative duty to take into account the public trust doctrine while planning and allocating water resources and also to protect public trust uses whenever feasible. ${ }^{52}$ Having analyzed the duty of the state and efficacy of public trust doctrine, the court thus extended the application of doctrine to groundwater resources which was not included by the traditional concept of public trust...53

The Supreme Court of California followed the footsteps extended the applicability of public trust to environmental impacts on navigable waters from excessive groundwater pumping. In the Environmental law Foundation v State Water resources Control Board ${ }^{54}$ it was held that 'public trust doctrine encompasses groundwater so connected to a navigable river that its extraction harms the uses of the river'. ${ }^{55}$ The case dealt with groundwater extraction impacts on Scott River,

49 9, P.3d 409 (Haw.2000) (para 135) cited in Paul (n 45) 6.

50 Ibid.

51 'The August,2000 Hawaii Supreme Court Wai Hole Ditch Decision: Comments and Excerpts regarding Public Trust Doctrine' 5< http://www.hawaii.edu/ohelo/pleadings/WaiholeSummary.pdf $>$ assessed 28th march 20168

52 Ibid.

53 Tuholske (n 1) 225.

54 Envtl. Law Found. v. State Water Res. Control Bd. No. 34-2010-80000583 (Cal. Super. Ct July 15, 2014) < http://www.envirolaw.org/documents/ScottOrderonCrossMotions.pdf $>$.

55 A. Bowling and E. Vissers, 'The Public Trust Doctrine and its Groundwater Application in California' $<$ https://journals.law.stanford.edu/stanford-environmental-law-journal-elj/blog/public-trust-doctrine-and-itsgroundwater-application-california\#sthash.ZXWYXJyK.dpuf>. 
This is the accepted version of: 'Groundwater Regulation in India: Applicability of Public Trust Doctrine and Right to Participation in Decision Making to achieve Right to Water.' In: Rehman, Javaid and Shahid, Ayesha, (eds.), Islamic Law and its Implementation in Asia and the Middle East. Leiden: Brill, pp. 327-349. (The Asian Yearbook of Human Rights and Humanitarian Law; Vol. 2). Published version available from: https://brill.com/abstract/book/edcoll/9789004346888/B9789004346888 012.xml Accepted version downloaded from SOAS Research Online: https://eprints.soas.ac.uk/26433/ in Siskiyou County, California which is used for recreational activities and fishing. The petitioners alleged that the excessive pumping of groundwater that is hydrologically so connected to Scott River contributed to dewatering of river leading to devastating impacts on marine population and navigability. ${ }^{56}$

In addition to these judicial opinions, several countries/states have provided statutory framework for the principle of Public Trust. National Water Act of South Africa provides that national government is the trustee of nation's water resources and has the responsibility of protecting those resources. ${ }^{57}$ New Hampshire in United States has declared that public trust doctrine extends to all waters in New Hampshire. ${ }^{58}$ It also provides in Chapter 485-C dealing with Groundwater Protection Act that state is responsible for 'groundwater management in the public trust and

56 Ibid. See also 'ELF v. State Water Resources Control Board et al' (Environmental Law Foundation) $<$ http://www.envirolaw.org/current>

57 Section 3 (1) of National Water Act 36 of 1998: [A]s the public trustee of the nation's water resources the National Government, acting through the Minister, must ensure that water is protected, used, developed, conserved, managed and controlled in a sustainable and equitable manner, for the benefit of all persons and in accordance with its constitutional mandate < https://www.dwa.gov.za/Documents/Legislature/nw_act/NWA.pdf>. See also D. Takacs, 'The Public Trust Doctrine, Environmental Human Rights, and the Future of Private Property' (2008)16 New York University Environmental Law Journal $711<$ http://www.ielrc.org/content/a0804.pdf>.

58 N.H REV.STAT.ANN, Section 481:1(2004): Declaration of Policy-[T]he general court finds that an adequate supply of water is indispensable to the health, welfare and safety of the people of the state and is essential to the balance of the natural environment of the state. Further, the water resources of the state are subject to an everincreasing demand for new and competing uses. The general court declares and determines that the water of New Hampshire whether located above or below ground constitutes a limited and, therefore, precious and invaluable public resource which should be protected, conserved and managed in the interest of present and future generations. The state as trustee of this resource for the public benefit declares that it has the authority and responsibility to provide careful stewardship over all the waters lying within its boundaries. $<$ http://www.gencourt.state.nh.us/rsa/html/L/481/481-1.htm>. See also Tuholske (n 1) 220. 
This is the accepted version of: 'Groundwater Regulation in India: Applicability of Public Trust Doctrine and Right to Participation in Decision Making to achieve Right to Water.' In: Rehman, Javaid and Shahid, Ayesha, (eds.), Islamic Law and its Implementation in Asia and the Middle East. Leiden: Brill, pp. 327-349. (The Asian Yearbook of Human Rights and Humanitarian Law; Vol. 2). Published version available from: https://brill.com/abstract/book/edcoll/9789004346888/B9789004346888 012.xml

Accepted version downloaded from SOAS Research Online: https://eprints.soas.ac.uk/26433/ interest.' ${ }^{59}$ Groundwater is included under public trust principle by Connecticut in its

Environment Protection Act (CEPA) ${ }^{60}$ where the relevant provision reads as: 'The State holds a public trust in the air, water and other natural resources of the State from unreasonable pollution, impairment or destruction provided no such action shall be maintained against the State for pollution of real property acquired by the State.' ${ }^{61}$

On analysis of the Public trust doctrine and judicial and statutory framework, it can be interpreted that the principle can be applied to groundwater preservation. Groundwater depletion has been increasing on an alarming rate in several parts of the world. Jack Tuholske, opines that though Public trust doctrine may not be a panacea for groundwater depletion but it can definitely

59 N.H REV.STAT.ANN. Section 485-C:1,(II)(2004): T]he legislature finds that the most effective means of preserving the existing high quality of groundwater is by identification and careful management of operations or activities which may cause contamination of groundwater if not properly conducted. Because groundwater is primarily a local resource, cities and towns should have the first opportunity to institute programs for groundwater protection within the scope of this chapter. Suppliers of water should also have this opportunity because of their vital interest in preserving the quality of their groundwater supply. The state, which has general responsibility for groundwater management in the public trust and interest, should develop groundwater protection programs within the scope of this chapter when such programs are not developed by a local entity < http://www.gencourt.state.nh.us/rsa/html/L/485-C/485-C-1.htm>. See also J Tuholske (n 1) 220.

60 Ibid. 220.

61 Connecticut Environment Protection Act, CONN. GEN.STAT Sec. 22a-16: Action for declaratory and equitable relief against unreasonable pollution: The Attorney General, any political subdivision of the state, any instrumentality or agency of the state or of a political subdivision thereof, any person, partnership, corporation, association, organization or other legal entity may maintain an action in the superior court for the judicial district wherein the defendant is located, resides or conducts business, except that where the state is the defendant, such action shall be brought in the judicial district of Hartford, for declaratory and equitable relief against the state, any political subdivision thereof, any instrumentality or agency of the state or of a political subdivision thereof, any person, partnership, corporation, association, organization or other legal entity, acting alone, or in combination with others, for the protection of the public trust in the air, water and other natural resources of the state from unreasonable pollution, impairment or destruction provided no such action shall be maintained against the state for pollution of real property acquired by the state under subsection (e) of section $22 \mathrm{a}-133 \mathrm{~m}$, where the spill or discharge which caused the pollution occurred prior to the acquisition of the property by the state. 
This is the accepted version of: 'Groundwater Regulation in India: Applicability of Public Trust Doctrine and Right to Participation in Decision Making to achieve Right to Water.' In: Rehman, Javaid and Shahid, Ayesha, (eds.), Islamic Law and its Implementation in Asia and the Middle East. Leiden: Brill, pp. 327-349. (The Asian Yearbook of Human Rights and Humanitarian Law; Vol. 2). Published version available from: https://brill.com/abstract/book/edcoll/9789004346888/B9789004346888 012.xml Accepted version downloaded from SOAS Research Online: https://eprints.soas.ac.uk/26433/ be an effective principle for its protection since it has been already applied to a variety of water issues. ${ }^{62}$ According to him, the fundamental principle of traditional version of public trust being the community ownership can be used suitably for the groundwater regulation unlike the reformed version of England and United States where the ownership vests with king and the states respectively. ${ }^{63}$

'The public trust implies the power not only to reactively protect resources but to also proactively respond to changing societal conditions before crisis situation arises'. ${ }^{64}$ This Statement of Hawaii Supreme Court also prompts the application of public trust to groundwater regulation since the problem of drinking water scarcity is acute in several parts of the world and the resources are depleting at an unhealthy level.

\section{The Application of Public Trust Doctrine by the Court in India and Legislative Developments}

Public trust doctrine is an inevitable part of environmental jurisprudence in India. ${ }^{65}$ The concept of trusteeship where the resources are owned by nation or state or community or a group

62 Tuholske (n 1) 221.

63 Ibid. 221-222.

64 9,P.3d 409 (Haw.2000) cited in C.N. Brown, 'Drinking from a Deep Well: The Public Trust Doctrine and Western Water Law' (2006) 34 Florida State University Law Review 1, 17.

65 S. Koonan, 'Legal Regime Governing groundwater in India' in P Cullet, AG Gualtieri, R Madhav and U Ramanathan, (ed.), Water law for the twenty-first century: National and International Aspects of Water law Reform in India (1 ${ }^{\text {st }}$ dn, Routledge 2010) 182-204 at 188. 
This is the accepted version of: 'Groundwater Regulation in India: Applicability of Public Trust Doctrine and Right to Participation in Decision Making to achieve Right to Water.' In: Rehman, Javaid and Shahid, Ayesha, (eds.), Islamic Law and its Implementation in Asia and the Middle East. Leiden: Brill, pp. 327-349. (The Asian Yearbook of Human Rights and Humanitarian Law; Vol. 2). Published version available from: https://brill.com/abstract/book/edcoll/9789004346888/B9789004346888 012.xml Accepted version downloaded from SOAS Research Online: https://eprints.soas.ac.uk/26433/ presupposes the obligation of a group as a whole and not individuals only. ${ }^{66}$ Though the principle is not an express part of any statute in the country, yet it has been incorporated in the environmental jurisprudence by the prudence of the Apex Court via its landmark judgments. $M C$ Mehta $v$ kamal nath ${ }^{67}$ laid the foundation of this principle in India. In this case the Supreme Court has expressly declared that ' $[\mathrm{t}]$ he State is the trustee of all natural resources which are by nature meant for public use and enjoyment. Public at large is the beneficiary of the sea-shore, running waters, airs, forests and ecologically fragile lands. The State as a trustee is under a legal duty to protect the natural resources. These resources meant for public use cannot be converted into private ownership' ${ }^{68}$ The case was regarding the issue that the then Minister of Environment and Forest, Kamal Nath (the respondent) misused his official authority to grant permission for building a Motel on the banks of the river Beas by changing the course of the river which created floods in the adjacent areas. The Court observed that, the notion that the public has a right to expect certain lands and natural areas to retain their natural characteristic is finding its way into the law of the land'69 by referring to landmark judgments from United States and the seminal article by Prof. Sax, ${ }^{70}$ 'Public trust doctrine' was declared as a part of the law of the land by the Court. ${ }^{71}$

\footnotetext{
66 Singh (n 42) 75.

67 (1997) 1 SCC 388

68 Ibid. (para 34).

69 Ibid. (para 23).

$70 \quad$ Sax (n 4) 471.

71 (1997) 1 SCC 388.
} 
This is the accepted version of: 'Groundwater Regulation in India: Applicability of Public Trust Doctrine and Right to Participation in Decision Making to achieve Right to Water.' In: Rehman, Javaid and Shahid, Ayesha, (eds.), Islamic Law and its Implementation in Asia and the Middle East. Leiden: Brill, pp. 327-349. (The Asian Yearbook of Human Rights and Humanitarian Law; Vol. 2). Published version available from: https://brill.com/abstract/book/edcoll/9789004346888/B9789004346888 012.xml Accepted version downloaded from SOAS Research Online: https://eprints.soas.ac.uk/26433/ This principle was reiterated by the Court in its several judgments later. ${ }^{72}$ Though the doctrine is effective in environmental regulations in India, applicability of the doctrine in water sector is limited to surface water only leaving out the applicability to groundwater doubtful. ${ }^{73}$ The Single judge Bench decision of Kerala high Court in Plachimada Dispute tried to apply the principle to groundwater regulation ${ }^{74}$ which unfortunately was overruled by the division bench of the same court. ${ }^{75}$ Balakrishnan Nair, J after referring to Supreme Court judgment on M C Mehta v Kamal Nath held that

Underground water belongs to the public. The State and its instrumentalities should act as trustees of this great wealth. State has got a duty to protect ground water against excessive exploitation and the inaction of the State in this regard will tantamount to infringement of the right to life of the people guaranteed under Article 21 of the Constitution of India. The Apex Court has repeatedly held that the right to clean air and unpolluted water forms part of the right to life under Article 21 of the Constitution. ${ }^{76}$

Groundwater in India is still ruled by Common law principle which link land ownership and groundwater. Right to water being considered as a basic human right and the country facing drinking water scarcity, Public trust doctrine can be an effective tool to regulate groundwater.

72 M.I Builders v Radhey Shyam Sahu 1999 SCC 464 where Public parks and market area are held to be public trust resources; Intellectual Forum, Thirupathi v State of Andhra Pradesh AIR 2006 SC 1350;. Fomento Resorts And Hotels Limited \& Anr. v Minguel Martins \& Ors, Civil Appeal No.4154 Of 2000; Salem Mavatta Ezhpulli Malaivazh vs The State Of Tamil Nadu(Writ Appeal No.376 of 2008 before High Court of madras), Karnataka Industrial Area Development Board v kenchappan (2006) 6SCC 371 RELIANCE Industries Limited $v$ Reliance Natural Resources Limited (2010) 7 SCC 1; Centre for Public Interest Litigation and others v. Union of India and other(2 G spectrum Case) Writ Petition (Civil) No. 423 OF 2010.

73 Konnan (n 65)188. See also P. Cullet, Water Law, Poverty and Development: Water Sector Reforms in India (1st edn, OUP 2009) 42.

74 Perumatty Grama Panchayat v State of Kerala 2004 (1) Kerala Law Times 31.

75 Hindustan Coco -Cola beverages v. Perumatty Grama Panchayat 2005 (2) Kerala Law Times 554.

76 Perumatty Grama Panchayat v State of Kerala 2004 (1) Kerala Law Times 31. 
This is the accepted version of: 'Groundwater Regulation in India: Applicability of Public Trust Doctrine and Right to Participation in Decision Making to achieve Right to Water.' In: Rehman, Javaid and Shahid, Ayesha, (eds.), Islamic Law and its Implementation in Asia and the Middle East. Leiden: Brill, pp. 327-349. (The Asian Yearbook of Human Rights and Humanitarian Law; Vol. 2). Published version available from: https://brill.com/abstract/book/edcoll/9789004346888/B9789004346888 012.xml Accepted version downloaded from SOAS Research Online: https://eprints.soas.ac.uk/26433/ Public trust doctrine as developed by the Roman law which vested the ownership of natural resources can also be extended to India. It was noted in Reliance Industries case, 'the constitutional mandate is that the natural resources belong to the people of this country. The nature of the word "vest" must be seen in the context of the Public Trust Doctrine. Even though this doctrine has been applied in cases dealing with environmental jurisprudence, it has its broader application'. ${ }^{77}$ The inability of the state to alienate the trust property being the important feature of this doctrine can be applied to groundwater particularly when the hydrologic connection with surface water can be demonstrated. ${ }^{78}$ Hence it can be extended to regulation of groundwater. Model Bill 2011 prepared by the Planning Commission of India has tried to incorporate the spirit of the doctrine recognizing groundwater as the common heritage of people of India held in trust by the state. ${ }^{79}$ National Water policy 2012 also reflects this approach. ${ }^{80}$ The ministry of water resources introduced a National water framework Bill in $2013^{81}$ 'to establish a

77 Reliance Natural Resources Ltd.v Reliance Industries Ltd Civil Appeal No. 4273 of 2010 (para 84).

78 M. Moench, 'Allocating the Common Heritage: Debates over Water Rights and Governance Structures in India.' (June 27 1998) Economic and Political weekly A-46, A-47, 48.

79 Chapter 3-Right to Water, Legal Status and Groundwater Use in Planning Commission Model Bill for the Conservation, Protection and Regulation of Groundwater, 2011: Groundwater is the common heritage of the people of India held in trust, for the use of all, subject to reasonable restrictions to protect all water and associated ecosystems. In its natural state, it is not amenable to ownership by the state, communities and persons. The state at all levels is the public trustee of ground water. The appropriate authority must ensure that water is protected, used, developed, conserved, managed and regulated in a sustainable and equitable manner, for the benefit of all persons and ecosystems. $<$ ielrc.org/content/e1118.pdf $>$.

80 Para 1.2(vi) of preamble of National Water Policy, 2012: [G]roundwater, though part of hydrological cycle and a community resource, is still perceived as an individual property and is exploited inequitably and without any consideration to its sustainability leading to its over-exploitation in several areas < http://wrmin.nic.in/writereaddata/NationalWaterPolicy/NWP2012Eng6495132651.pdf>

81 Press Information Bureau of India, 'Water Resources Ministry Releases Draft National Water Framework Bill, Draft River Basin Management Bill and Draft National Policy Guidelines for Water Sharing/Distribution 
This is the accepted version of: 'Groundwater Regulation in India: Applicability of Public Trust Doctrine and Right to Participation in Decision Making to achieve Right to Water.' In: Rehman, Javaid and Shahid, Ayesha, (eds.), Islamic Law and its Implementation in Asia and the Middle East. Leiden: Brill, pp. 327-349. (The Asian Yearbook of Human Rights and Humanitarian Law; Vol. 2). Published version available from: https://brill.com/abstract/book/edcoll/9789004346888/B9789004346888 012.xml Accepted version downloaded from SOAS Research Online: https://eprints.soas.ac.uk/26433/ framework with governing principles for protection, conservation and regulation of waters' ${ }^{82}$

The Bill envisages water as a common pool resource of the community which is to be managed, protected and preserved by community based institutions. ${ }^{83}$ The public trust principle is also incorporated when the bill provides that water is held by the state as trustee which shall remain with the State even if some of its functions with respect to trust property is conveyed to any public or private agency. ${ }^{84}$ The most recent bill introduced by the Central Government in 2017The Groundwater Sustainable Management Act 2016 aims to introduce the concept of Public Trust Doctrine in governing and managing groundwater resources in the country. However this is a draft bill introduced by the Central Government. As per the existing conditions in the country, this should be introduced by the state governments in their respective state legislations. The existing laws in the states are based on the 2005 draft bill, which again was the copy of the 1970 bill. Interestingly the most water exploiting state of Punjab doesn't have a state law on groundwater resources. If this is the situation in India, then public trust doctrine to be in force,

\footnotetext{
Amongst States for Comments by Next Month End' (24 June 2013) <
http://pib.nic.in/newsite/PrintRelease.aspx?relid=96713>.

82 Preamble to the Draft National Water Framework Bill,2013 < http://www.indiaenvironmentportal.org.in/files/file/Draft\%20national\%20framework\%20bill,\%202013.pdf> assessed 30 March 2016.This bill is envisaged as only a framework and no administrative machinery or institutional structure other than National information machinery is envisaged at the Central level. It is an umbrella legislation providing for a uniform set of principles to be applied by Centre, States and the local governments. Hence it is not envisaged to change the Centre-state relations with regard to the legislative capability on water sector which is primarily under the legislative competence of the States concerned. < http://www.planningcommission.nic.in/aboutus/committee/wrkgrp12/wr/wg_wtr_frame.pdf $>$

83 According to section 3 (4) of the Draft Bill: [W]ater is a common pool resource of the community and shall be managed, protected and preserved as such by community based institutions.

84 According to section 3(5) of the Draft Bill: [T]he State holds water in public trust for the people and is obliged to protect water resources as a trustee for the benefit of all. Provided that the responsibility of the state as public trustee shall remain even if some of the functions of the state in relation to water are entrusted to any public or private agency.
} 
This is the accepted version of: 'Groundwater Regulation in India: Applicability of Public Trust Doctrine and Right to Participation in Decision Making to achieve Right to Water.' In: Rehman, Javaid and Shahid, Ayesha, (eds.), Islamic Law and its Implementation in Asia and the Middle East. Leiden: Brill, pp. 327-349. (The Asian Yearbook of Human Rights and Humanitarian Law; Vol. 2). Published version available from: https://brill.com/abstract/book/edcoll/9789004346888/B9789004346888 012.xml Accepted version downloaded from SOAS Research Online: https://eprints.soas.ac.uk/26433/ there should be wholehearted approach from the states to accept the water crisis and introduction of the bill in their respective states.

Central Government is moving towards the establishment of public trust doctrine with regard to water resources through its efforts. However, Philippe Cullet notes that yet, it will not be the complete solution for the problems identified with the complete assertion of power under the doctrine of eminent domain. ${ }^{85}$ Ramaswamy Iyer points that the doctrine must not only be applied between state and Civil society but also among generations, between humanity and nature thus providing it a wide interpretation and ecological underpinning. ${ }^{86}$ So far now the development of the public trust doctrine in India is done by the judiciary. There is no statute which establishes the principle in any natural resources conservation other than these draft bills of 2011 and 2013. When the Constitution provides that water is under the legislative purview of the States and after 73rd Amendment Act, it being under the competence of local self-governing bodies, unless there is no constitutional support for the doctrine it would be difficult to establish and implement in groundwater conservation. Public trust will not be meaningful and effective unless there is provision for public participation in decision making.

\section{Public participation in decision making}

Public Participation is essentially concerned with informing, consulting and involvement of the beneficiary (Public) in planning, environmental management and impact assessment of vital

85 Cullet (n 41) 43 .

86 R. Iyer, 'A Synoptic Survey and thoughts on Change' in R. Iyer (ed.), Water and the laws in India (SAGE LAW 2009) 568- 623 at 587. 
This is the accepted version of: 'Groundwater Regulation in India: Applicability of Public Trust Doctrine and Right to Participation in Decision Making to achieve Right to Water.' In: Rehman, Javaid and Shahid, Ayesha, (eds.), Islamic Law and its Implementation in Asia and the Middle East. Leiden: Brill, pp. 327-349. (The Asian Yearbook of Human Rights and Humanitarian Law; Vol. 2). Published version available from: https://brill.com/abstract/book/edcoll/9789004346888/B9789004346888 012.xml

Accepted version downloaded from SOAS Research Online: https://eprints.soas.ac.uk/26433/

projects. ${ }^{87}$ Public Participation has been defined as "purposeful activities in which citizens take

part in relation to government' ${ }^{88}$ There are four components in it: first is the purpose for which participation is undertaken, type of action, people involved and government entities targeted. ${ }^{89}$ Public participation takes different forms ranging from education and information, review and reaction, to interaction and dialogue. ${ }^{90}$ It includes public advocacy, protests, public hearings, solicitation of public comments, involvement of political party and judiciary. ${ }^{91}$ Though the concept evolved in the early twentieth century, it received global attention since $1980 \mathrm{~s}^{92}$ only when World Commission on Environment and Development (WCED) published Our Common Future (1987) (the Brundtland Report). ${ }^{93}$ The most fundamental provision in a multilateral agreement calling for effective public participation is Principle 10 of the Rio Declaration ${ }^{94}$ which

87 B.D. Clark, 'Improving Public Participation in Environmental Impact Assessment Built Environment (1978-)' (1994) 20(4) Environmental Impact Assessment: The Next Steps? 294-308< http://www.jstor.org/stable/23287802>.

88 N.P. Spyke, 'Public Participation in Environmental Decision making at the New Millennium: Structuring New Spheres of Public Influence.' (1999) 26 Boston College Environmental Affairs Law Review 263, 266.

89 Ibid.

$90 \quad$ P Wilkinson, 'Public participation in environmental management: A case study' (1976) 16 Natural Resources Journal 117,119.

91 R. Ramlogan, Sustainable Development towards a Judicial Interpretation (Martinus Nijhoff 2011)163.

92 E. Toomey, 'Public Participation in Resource Management: The New Zealand Experience' (2012) 16 New Zealand Journal of Environmental Law 117,120.

93 According to the Report of the World Commission on Environment and Development, 'Our Common Future': 'Sustainable development is development that meets the needs of the present without compromising the ability of future generations to meet their own needs. It contains within it two key concepts: the concept of 'needs', in particular the essential needs of the world's poor, to which overriding priority should be given; and the idea of limitations imposed by the state of technology and social organization on the environment's ability to meet present and future needs.' $<$ http://www.un-documents.net/our-common-future.pdf $>$.

94 Rio Declaration on Environment and development, 1992< $<\mathrm{http}$ //www.unep.org/documents.multilingual/default.asp?documentid=78\&articleid=1163>. 
This is the accepted version of: 'Groundwater Regulation in India: Applicability of Public Trust Doctrine and Right to Participation in Decision Making to achieve Right to Water.' In: Rehman, Javaid and Shahid, Ayesha, (eds.), Islamic Law and its Implementation in Asia and the Middle East. Leiden: Brill, pp. 327-349. (The Asian Yearbook of Human Rights and Humanitarian Law; Vol. 2). Published version available from: https://brill.com/abstract/book/edcoll/9789004346888/B9789004346888 012.xml Accepted version downloaded from SOAS Research Online: https://eprints.soas.ac.uk/26433/ focuses on its significance to handle environmental issues at all relevant level with the citizens having appropriate access to information concerning the environment. ${ }^{95}$

World Summit on Sustainable Development Plan of Implementation, 2002 has incorporated the principle10 of Rio Declaration in paragraph 128 when it provides that: '[E]nsure access, at the national level, to environmental information and judicial and administrative proceedings in environmental matters, as well as public participation in decision-making, so as to further principle 10 of the Rio Declaration on Environment and Development, taking into full account principles 5, 7 and 11 of the Declaration'. ${ }^{96}$ The Aarhus Convention ${ }^{97}$ signed in 1998 can be considered as the bible for the public participation in environment issues. It aims to ensure more transparency and accountability in the Environmental Decision-Making (EDM) process in Energy sector, Nuclear Energy and Genetically Modified Organisms. ${ }^{98}$ The convention works on three important pillars: the right of citizens to access information, their right to participate in

95 Principle 10 of the Rio Declaration provides: Environmental issues are best handled with participation of all concerned citizens, at the relevant level. At the national level, each individual shall have appropriate access to information concerning the environment that is held by public authorities, including information on hazardous materials and activities in their communities, and the opportunity to participate in decision-making processes. States shall facilitate and encourage public awareness and participation by making information widely available. Effective access to judicial and administrative proceedings, including redress and remedy, shall be provided.

96 'Plan of Implementation of the World Summit on Sustainable Development' $<$ http://www.un.org/esa/sustdev/documents/WSSD_POI_PD/English/WSSD_PlanImpl.pdf $>$.

97 UNECE Convention on Access to Information, Public Participation in Decision-making and Access to Justice in Environmental Matters (adopted 25 June 1998 entered into force 30 October 2001) (Aarhus Convention)< http://www.unece.org/fileadmin/DAM/env/pp/documents/cep43e.pdf>.

98 A. Agarwal and S. Narain, 'Power To People' in A. Agarwal, S. Narain, A. Sharma and A. Imchen (eds.), Poles Apart, Global Environmental Negotiations 2 (Centre for Science and Environment 2001)139 at 143. 
This is the accepted version of: 'Groundwater Regulation in India: Applicability of Public Trust Doctrine and Right to Participation in Decision Making to achieve Right to Water.' In: Rehman, Javaid and Shahid, Ayesha, (eds.), Islamic Law and its Implementation in Asia and the Middle East. Leiden: Brill, pp. 327-349. (The Asian Yearbook of Human Rights and Humanitarian Law; Vol. 2). Published version available from: https://brill.com/abstract/book/edcoll/9789004346888/B9789004346888 012.xml

Accepted version downloaded from SOAS Research Online: https://eprints.soas.ac.uk/26433/

EDM and right to access justice in environmental matters. ${ }^{99}$ Member states are required to

implement national legislations to ensure that information is available to the public and facilitate participation in decision making process and ensure easy access to justice in environmental matters. ${ }^{100}$ The convention calls upon the member states to provide for public participation in a transparent and fair framework during the preparation of plans, policies and programs relating to Environment. ${ }^{101}$ Although this is a global Convention, it has ignited interest in other parts of the world has been upheld as the appropriate model for a universal Convention. ${ }^{102}$

It is inevitable in case of an environmental decision making to take into account public interest. ${ }^{103}$ It is through the participation of the people, the interested and affected individuals, organizations

99 Ibid. According to article 1 of the Convention: [I]n order to contribute to the protection of the right of every person of present and future generations to live in an environment adequate to his or her health and well-being, each Party shall guarantee the rights of access to information, public participation in decision-making, and access to justice in environmental matters in accordance with the provisions of this Convention.

100 According to article 3(1) of the Convention: [E]ach Party shall take the necessary legislative, regulatory and other measures, including measures to achieve compatibility between the provisions implementing the information, public participation and access-to-justice provisions in this Convention, as well as proper enforcement measures, to establish and maintain a clear, transparent and consistent framework to implement the provisions of this Convention.

101 According to article 7 of the Convention: [E]ach Party shall make appropriate practical and/or other provisions for the public to participate during the preparation of plans and programmes relating to the environment, within a transparent and fair framework, having provided the necessary information to the public.

102 Agarwal and Narain (n 98) 143. Kofi Annan, the former Secretary-General, United Nations opined: 'The Aarhus Convention is the most ambitious venture in environmental democracy undertaken under the auspices of the United Nations. Its adoption was a remarkable step forward in the development of international law.... The firm commitment to [the Convention's] principles of ... States in Eastern Europe and Central Asia ... clearly demonstrates that environmental rights are not a luxury reserved for rich countries... We must use next year's World Summit on Sustainable Development to strengthen our commitment to environmental rights-not only in Europe but throughout the world'. https://www.unece.org/fileadmin/DAM/env/pp/documents/statements.pdf>.

103 M. Jeffrey, 'Intervenor Funding as the Key to Citizen Participation in Environmental Decision Making: Putting People back into the picture' (2002) 19 Arizona Journal of International \& Comparative Law 643, 645. 
This is the accepted version of: 'Groundwater Regulation in India: Applicability of Public Trust Doctrine and Right to Participation in Decision Making to achieve Right to Water.' In: Rehman, Javaid and Shahid, Ayesha, (eds.), Islamic Law and its Implementation in Asia and the Middle East. Leiden: Brill, pp. 327-349. (The Asian Yearbook of Human Rights and Humanitarian Law; Vol. 2). Published version available from: https://brill.com/abstract/book/edcoll/9789004346888/B9789004346888 012.xml

Accepted version downloaded from SOAS Research Online: https://eprints.soas.ac.uk/26433/

and governmental entities can be consulted and make them part of the decision making process. ${ }^{104}$ This can encourage the accountability of the implementing authorities, ensuring a participatory democratic process and can even stimulate certain novel and socially acceptable solutions to the environmental issues. ${ }^{105}$ Public participation ensures better rules enhancing the effectiveness of the democratic process. ${ }^{106}$ For an effective participation, requirements include:

- $\quad$ education about the environment and things that might affect it;

- access to information( including the fact that information exists and is available);

- a voice in decision-making;

- transparency of decisional processes (by formal consideration of public input and explanation of how that input affected the decision at issue);

- $\quad$ post-project analysis and monitoring, as well as access to pertinent information;

- enforcement structures; and

- Recourse to independent tribunals for redress.

Added to these elements, each to be effective, there should be mechanism of protection available to the public against the government or other proponents involved in the activity. ${ }^{107}$ The degree and manner of participation varies depending on the subject, legal framework and the political and social will. ${ }^{108}$ In USA, the people enjoy the right to participate at both rule making and adjudicatory level where The Administrative Procedures Act (APA) and the National

104 A.N. Bram, 'Public Participation Provisions Need Not Contribute to Environmental Injustice' (1996) 5 Temple Political \& Civil Rights Law Review 145, 150-151 cited in Jeffrey (n 103) 649.

105 Ibid. 649.

106 J.C. Duncan, Jr., 'Multicultural Participation in the Public Hearing Process: Some Theoretical, Pragmatical, and Analeptical Consideration' (1999) 24 Columbia Journal of Environmental Law 169,171.

107 N.A.F. Popovic, 'The Right to Participate in Decisions That Affect the Environment' (1993)10 Pace Environmental Law Review 683, 691

108 Ramlogan (n 91) 164. 
This is the accepted version of: 'Groundwater Regulation in India: Applicability of Public Trust Doctrine and Right to Participation in Decision Making to achieve Right to Water.' In: Rehman, Javaid and Shahid, Ayesha, (eds.), Islamic Law and its Implementation in Asia and the Middle East. Leiden: Brill, pp. 327-349. (The Asian Yearbook of Human Rights and Humanitarian Law; Vol. 2). Published version available from: https://brill.com/abstract/book/edcoll/9789004346888/B9789004346888 012.xml Accepted version downloaded from SOAS Research Online: https://eprints.soas.ac.uk/26433/ Environmental Policy Act (NEPA) constitute two of the main sources for expanding public participation in national environmental administrative decision making. ${ }^{109}$ If the participation is ensured at the individual level, it shall create a sense of self-confidence and shared control of government or a greater control of one's own life leading to a trust being generated among the masses that decision making process is democratic. ${ }^{110}$ Since government derives its power from the people in democracy, every citizen has the right to participate in the decision making process with the obligation upon the government to respond thereby making the citizens the 'real watch dog of democracy.' 111

Environment Impact Assessment (EIA) provides a framework for ensuring public participation in environmental decision-making by ensuring access to information, opportunity to express opinions, transparency in decision making, and implementation and enforcement mechanisms. ${ }^{112}$ EIA procedures ensure that environmental consequences of projects are identified and assessed before authorization is granted for initiating the project. ${ }^{113}$ In India, EIA is compulsory for projects for 29 categories of developmental activities involving investments of Rs. 50 crores and

109 Jeffrey (n 103) 650.

110 Ramlogan (n 91)164.

111 N.P. Spyke, 'Public Participation in Environmental Decision making at the New Millennium: Structuring New Spheres of Public Influence.' (1999) 26 Boston College Environmental Affairs Law Review 263, 271; see also Ramlogan (n 91)164.

112 Ibid.

113 Ibid. 166. 
This is the accepted version of: 'Groundwater Regulation in India: Applicability of Public Trust Doctrine and Right to Participation in Decision Making to achieve Right to Water.' In: Rehman, Javaid and Shahid, Ayesha, (eds.), Islamic Law and its Implementation in Asia and the Middle East. Leiden: Brill, pp. 327-349. (The Asian Yearbook of Human Rights and Humanitarian Law; Vol. 2). Published version available from: https://brill.com/abstract/book/edcoll/9789004346888/B9789004346888 012.xml Accepted version downloaded from SOAS Research Online: https://eprints.soas.ac.uk/26433/ above under the Environmental (Protection) Act, 1986. ${ }^{114}$ In any of these there is no mandatory rule to assure groundwater non-exploitation.

\section{Public Participation and Groundwater Resources}

Public participation should be made mandatory in projects involving groundwater extraction. Once the resource has been declared as Common resource of the community held by the state in public trust and read in line with the right to water being declared as fundamental right, public is entitled to receive information and right to take part in decision making in the activities affecting the resource. In India, there are water user associations established by the state irrigation acts which are however for ensuring limited participation in certain specific tasks only. ${ }^{115}$ The Plachimada incident in Kerala opens our eyes for the need to strengthen the participatory mechanism in regulating groundwater. Panchayat should be granted the complete authority to take decisions on grant of permit and cap of extraction limit after consultation with the groundwater authority of the State which can provide technical know-how. Panchayat is the lowest level where people can be effectively participated in day to day affairs especially with regard to groundwater in a Country like India where many parts face water scarcity. Public trust and public participation are complementary.

114 Ministry of Environment and Forest, Government of India. $<$ http://www.moef.gov.in/division/introduction-8>.

115 P. Cullet, 'Water Regulation and Public Participation in the Indian Context' in M. Tignino \& K. Sangabana (eds.), Public Participation and Water Resources Management: Where Do We Stand in International Law? (UNESCO 2015) 20-29 at 25 
This is the accepted version of: 'Groundwater Regulation in India: Applicability of Public Trust Doctrine and Right to Participation in Decision Making to achieve Right to Water.' In: Rehman, Javaid and Shahid, Ayesha, (eds.), Islamic Law and its Implementation in Asia and the Middle East. Leiden: Brill, pp. 327-349. (The Asian Yearbook of Human Rights and Humanitarian Law; Vol. 2). Published version available from: https://brill.com/abstract/book/edcoll/9789004346888/B9789004346888 012.xml Accepted version downloaded from SOAS Research Online: https://eprints.soas.ac.uk/26433/

In the recent bill on Groundwater resources 2016, the Central Government tries to incorporate decentralized approach in managing the resources. The Bill envisage different tiers of institutional framework-groundwater subcommittee at grama panchayat level, groundwater management committee at the block panchayat and municipal levels, district groundwater councils and groundwater advisory councils at the state levels. It also envisages the social and environmental impact assessment and public consultation provisions. Duties are corollary to rights. When the bill guarantees the fundamental right to water to citizens, it also makes the citizens duty bound to protect the water resources by including the provision of 'duties of groundwater users' in the bill.

However, to ensure effective participation at rule making and adjudicatory process, there should be shift in the common law principle linking groundwater to land ownership to declaring it as a public trust with a statutory framework. Public trust in water resources especially groundwater should be made the law of the land-basic structure of the law which cannot be deviated in any circumstances.

\section{Conclusion}

India is one of the largest groundwater user countries in the world. Over reliance on this resource irrespective of hydrological availability, has resulted in falling of water table in several areas. In order to ensure groundwater conservation and preservation, strong legal interventions are required. Presently groundwater resources are still governed by the common law principles of 'chattel attached to land' which allows the land owners to extract as much as required from their land. Moreover there is no legal remedy for neighboring land owners against each other's over 
This is the accepted version of: 'Groundwater Regulation in India: Applicability of Public Trust Doctrine and Right to Participation in Decision Making to achieve Right to Water.' In: Rehman, Javaid and Shahid, Ayesha, (eds.), Islamic Law and its Implementation in Asia and the Middle East. Leiden: Brill, pp. 327-349. (The Asian Yearbook of Human Rights and Humanitarian Law; Vol. 2). Published version available from: https://brill.com/abstract/book/edcoll/9789004346888/B9789004346888 012.xml Accepted version downloaded from SOAS Research Online: https://eprints.soas.ac.uk/26433/ use. This situation also leads to an assumption- if you own land, you can access groundwater, or else, no access; leading to denial of human right to water for landless. Legal framework in India regarding water resources is fragmented with national water policies, state water policies and state laws. As Constitution mandates the power of law making on water resources to the states, there are state laws in several states which are enacted on the basis of Model Bill circulated by the central government. But these laws have not changed the existing legal regime. They aim to declare 'notified area' in the over exploiting areas so as to reduce such water consumption. These legislations aim to introduce registering wells and licensing systems for ground water use without changing the existing nature of groundwater-landownership nexus.

Application of Public Trust Doctrine to groundwater resources attracts significance in this situation. The principle has been applied by Supreme Court of India to surface water resources in MC Mehta case which has not been applied to ground water resources. Hydrological link between surface water and groundwater has been neglected while enacting laws. As all waters are interlinked, application of this doctrine to groundwater can be assumed if it is applied to surface water. However as there is neither law nor any judicial pronouncements, it has not yet applied. Decision of Single Bench of Kerala High Court in Plachimada case was ground breaking decision where the judge prudently applied this doctrine for groundwater protection. Recent bills introduced by the central government including National Water Framework Bill, 2016 and Model Groundwater (Sustainable Management) Act 2016 have tried to incorporate this principle. Since these bills have not been enacted as 'laws', long wait yet required to receive public trust status for groundwater which is very essential to ensure its sustainable conservation and management. 
This is the accepted version of: 'Groundwater Regulation in India: Applicability of Public Trust Doctrine and Right to Participation in Decision Making to achieve Right to Water.' In: Rehman, Javaid and Shahid, Ayesha, (eds.), Islamic Law and its Implementation in Asia and the Middle East. Leiden: Brill, pp. 327-349. (The Asian Yearbook of Human Rights and Humanitarian Law; Vol. 2). Published version available from: https://brill.com/abstract/book/edcoll/9789004346888/B9789004346888 012.xml Accepted version downloaded from SOAS Research Online: https://eprints.soas.ac.uk/26433/

Public Trust Doctrine mandates the state to be the trustee of natural resources of the country for the benefit of all people. When the state acts as trustee, more obligations are casted upon state machinery not only to preserve these resources but also to ensure equitable availability of these resources to beneficiaries. Public participation in decision making is considered to be one of the pivotal steps to ensure equitable access and enjoyment. Once the decision making power is shared by the rulers and the ruled, effective decisions would be the outcome especially in matters of environment. As water resources are core of life and livelihood, matters with respect to water resources should include participation of community. Water user associations have been given participation in certain matters by water laws in some states in India. With respect to groundwater, which is region specific in quantity and quality, participation at the community level will boost the conservation element. Decentralization of powers in the Constitution of India empowers Panchayats to take decisions in matters including drinking water. New bills introduced by the central government also aim to ensure community level participation in groundwater preservation.

Unless there is a change in legal framework regarding groundwater resources and applying public trust doctrine as a means for state control, this invisible 'blue gold' cannot be protected, preserved and conserved. For the same, public participation can be a means to ensure community level involvement. Hence to ensure right to water and equitable access to groundwater resources, introduction of public trust doctrine and public participation in decision making is inevitable. 
This is the accepted version of: 'Groundwater Regulation in India: Applicability of Public Trust Doctrine and Right to Participation in Decision Making to achieve Right to Water.' In: Rehman, Javaid and Shahid, Ayesha, (eds.), Islamic Law and its Implementation in Asia and the Middle East. Leiden: Brill, pp. 327-349. (The Asian Yearbook of Human Rights and Humanitarian Law; Vol. 2). Published version available from:

https://brill.com/abstract/book/edcoll/9789004346888/B9789004346888 012.xml

Accepted version downloaded from SOAS Research Online: https://eprints.soas.ac.uk/26433/ 